\title{
FACTORS ASSOCIATED WITH THE CHOICE OF FEMALE SURGERY CONTRACEPTIVE METHOD: APPLICATION OF SOCIAL COGNITIVE THEORY
}

\author{
Ainul Maghfiroh'), Uki Retno Budihastuti²), \\ Ismi Dwi Astuti Nurhaeni3) \\ 1)Masters Program in Public Health, Universitas Sebelas Maret \\ 2)Department of Obstetrics and Ginecology, Dr. Moewardi Hospital, Surakarta \\ 3)Faculty of Social and Politic Sciences, Universitas Sebelas Maret
}

\begin{abstract}
Background: Population growth control can ideally be achieved in three ways; raise mortality, promote migration, lower fertility. While the first way is widely unacceptable and the second infeasible, the third way has become the goal of most population control policies and interventions. The purpose of this study was to examine factors associated with the choice of female surgery contraceptive method using Social Cognitive Theory.

Subjects and Method: This was an analytic observational study with a case control design. This study was conducted in Kendal, Central Java. A sample of 200 women of reproductive age was selected by fixed disease sampling. The dependent variable was female surgery contraceptive method. The independent variables were age, education, knowledge, attitude, self-efficacy, perception of gender equality, number of children alive, employment, and husband support. The data were collected by questionnaire and analyzed by a multiple logistic regression.

Results: The choice of female surgery contraceptive method was positively associated with age $<20$ or $\geq 35$ years $(b=1.57 ; 95 \% \mathrm{CI}=0.34$ to $2.79 ; \mathrm{p}=0.012)$, number of children alive $(b=1.74 ; 95 \% \mathrm{CI}=0.61$ to $2.88 ; \mathrm{p}=0.003)$, employment $(\mathrm{b}=1.14 ; 95 \% \mathrm{CI}=0.07$ to 2.21; $\mathrm{p}=0.037)$, positive attitude $(\mathrm{b}=1.56 ; 95 \% \mathrm{CI}=0.45$ to $2.66 ; \mathrm{p}=0.006)$, high education $(b=1.18 ; 95 \% \mathrm{CI}=0.02$ to $2.35 ; \mathrm{p}=0.045)$, knowledge $(\mathrm{b}=1.91 ; 95 \% \mathrm{CI}=0.80$ to $3.02 ; \mathrm{p}=0.001)$, self-efficacy $(\mathrm{b}=1.61 ; 95 \% \mathrm{CI}=0.48$ to $2.74 ; \mathrm{p}=0.005)$, strong husband support $(\mathrm{b}=1.24 ; 95 \% \mathrm{CI}=0.14$ to $2.33 ; \mathrm{p}=0.027)$, and perception of gender equality $(b=1.25 ; 95 \% \mathrm{CI}=0.18$ to $2.32 ; \mathrm{p}=0.021)$.

Conclusion: The choice of female surgery contraceptive method is positively associated with age, number of children alive, employment, positive attitude, high education, knowledge, self-efficacy, strong husband support, and perception of gender equality.
\end{abstract}

Keywords: female surgery contraceptive method, Social Cognitive Theory

Correspondence:

Ainul Maghfiroh. Masters Program in Public Health, Universitas Sebelas Maret, Jl. Ir. Sutami 36 A, Surakarta 57126,, Central Java, Indonesia.

Email: Ainulmaghfiroho504@gmail.com. Mobile: +6285641012090. 